\title{
THE PHILOSOPHY OF ART BY GÜNTER GRASS
}

\begin{abstract}
This article is dedicated to the philosophy of art by Nobel Prize laureate and German national poet Günter Grass. Its focuses on Grass's understanding of art and reality, ambivalence and relativism, his conception of imagination and reflection and the position of the language in it. In addition, the paper presents the interrelationship between Grass's philosophy of art and its expression in narration. The focus of the consideration is the novels "The Tin Drum" and "A Wide Field". Finally, the article pays special attention to Grass's concept of reflection, which is placed in the philosophical context of the Romantic understanding of irony. This allows parallels to be drawn between Schlege's and Grass's philosophical positions.
\end{abstract}

Keywords: ambivalence, relativism, reflection, contradictions, multiplicity of realities, "creating" and "discarding".

\section{Introduction}

For Grass (1987a), art is ostensibly a "medium for criticising reality and a means of problematising historical reality" (p. 185). He sees his task as a writer primarily in mirroring reality and, in general, the conceptions of what "reality" is and how it is constructed in each culture or subject. If Grass is considered a "magic realist", it means that he repeatedly transgresses the boundaries of "reality" conventions into the fantastic, without, however, abandoning them completely. By "reality", however, Grass means its refraction and not reality as a whole because, according to Grass, only its refraction ${ }^{1}$ shows what reality is. ${ }^{2}$

The most important starting point in Grass's (1987b) understanding of reality is the assumption of a multiplicity of realities: "We had be-

1 In the context of Grass's poetics, refraction is understood above all as multiperspectivity.

2 Cf. Grass's reference to Alfred Döblin as Grass's literary model: "Döblin smashes all this several times and consciously into shards, so that reality emerges." In Günter Grass. WA, Bd. IX, S. 244. The principle of shattering finds its way above all in the novel "The Tin Drum", specifically in the art of Oskar's "Glaszersingen" (shattering glass by singing). In Günter Grass. WA, Bd. II. „Die Blechtrommel“, S. 71f. come accustomed to speaking of only one reality at a time. However, I have encountered several realities that exclude each other, realities that are hidden, covered by another reality. The work of art ... has the possibility of making the multiplicity of realities clear" (p. 244). ${ }^{3}$

Consequently, Grass (1987a) pleads for distrust of the "reduced concept of reality" (p. 261). For Grass, the writer and Nobel Prize laureate, the world can only exist in the form of contradictions. His ideas of the ambivalence of truth and a fundamental relativism in the sense of relativizing all values, facts and conditions derive from it. Grass is simply concerned in his work to show the dichotomy of a situation, a fact, etc., and create tension.

In a poetic and epistemological sense, the idea of another alternative truth is reflected in the play with possibilities of reality, leading to the relativism of narrative. It is crucial for Grass (1987c) to show the truth in its ambivalence: this is reflected in the so-called "third", in the process of the negation of black-and-white thinking, more pre-

Pointing out the "multiplicity of realities" in the context of the reunification process is the actual intention of the novel "A Wide Field". 
cisely formulated - in the "shade of grey" (p. 658). ${ }^{4}$

His narration, conceived as both/and, represents a polarisation of the possibilities of reality and a depalletization of truth aiming at principal irresolvability. ${ }^{5}$ In Grass's narrative work, this is reflected in antithetically conceived constellations of characters, potentiations of the narrative perspective, the multiplicity of narrative strands that depict the multiplicity of realities. The same applies to the language game as a differentiation of the expressive sides of language. One's own (narrated) reality is thereby necessarily questioned.

In depicting the multiplicity of realities, Grass thus depends on concepts such as doubt, scepticism and disbelief, which become the program$\mathrm{me}^{6}$ as components of critical thinking. Thus, the visualisation of the ambivalence of truth through art and literature is under the sign of the Enlightenment.

\section{Main Text}

Grass's understanding of art thus includes the imagination of other realities called to question absolute truth.

Grass's thinking about ambivalence and relativism is reflected, for example, in the Goethe/ Rasputin duality in the novel "The Tin Drum": "I did not want to rely on Rasputin alone, for all too soon it became clear to me that in this world there is Goethe opposite every Rasputin, that Rasputin draws Goethe and Goethe draws Rasputin after him, even creates him, if need be, in order to be able to condemn afterwards." (Allein auf Rasputin wollte ich mich nicht verlassen,

4 On the colour grey and its significance for Grass cf. "With them everything was black or white, yes or no; but Grass's and Doubt's colour is grey." In Volker Neuhaus: Nachwort zu „Aus dem Tagebuch einer Schnecke“. In Günter Grass. WA, Bd. IV, S. 586.

5 This phenomenon goes back to romantic philosophy.

6 Ambiguity and contradiction are personified by Grass in "Aus dem Tagebuch einer Schecke" ("From the diary of a pinto") in the character Hermann Otts, alias Dr. Zweifel. Cf. In Günter Grass. WA, Bd. IV, S. 280, 284f. und 293. denn allzubald wurde mir klar, daß auf dieser Welt jedem Rasputin ein Goethe gegenübersteht, daß Rasputin Goethe und der Goethe einen Rasputin nach sich zieht, sogar erschafft, wenn es sein muß, um hinterher verurteilen zu können.) (Grass, 1987e, p. 105). In this dualism, Grass underscores basic principles of the world (in the juxtaposition of white/black, light/dark, thinker/demon, spirit/drive) and of life (knowledge, education, maturity versus lust, pleasure, sensuality). Using Oskar as an example, Grass identifies the structure of Being as fundamentally antithetical. It follows that, like Oskar, one should understand dualism as a law of the world, in other words - recognise the immanent antithesis of reality. This realisation is related to the (artistic) production of duality or making conscious of an antithetical. The realisation of duality does not mean overcoming through reconciliation (the levelling of polarities), but the perception of the parallelism of opposites, their simultaneous validity and effectiveness. Only in this case are cognition and critique possible. One could conclude from this that the didactic goal of (narrative) art according to Grass consists precisely in leading to the insight of the realisation of ambivalence and relativism.

For the writer Grass, the reality is the starting point of poetic imagination and reflection. For him, empirical reality and its experience are the conditions for artistic self-understanding: if art does not subject itself to self-criticism, it isolates itself from socio-political responsibility. Without the artist's participation in his everyday life, his art would be idealistic and aestheticistic, and his attitude simply uncritical.

Furthermore, we focus on the concept of reflection by Günter Grass. Grass (1987b) understands reflection primarily as self-criticism (pp. 6-14). Christian Auffenberg (1993) places Grass's concept of reflection in the philosophical context of the Romantic understanding of irony. Indeed, a comparison can be drawn between a Grass quote and Schlegel's definition of irony. According to Grass (1987b): “A true poet must 
have such and constantly proliferating amount of imagination that he is no longer dependent on it" (p. 20). Friedrich Schlegel (1882) understands reflection concerning the artist as "the freest of licences, for through it one removes oneself' (p. 188).

According to Ingrid Strohschneider-Kohrs (1978), Schlegel transforms this thought into a philosophical postulate: the artist must free himself from an "illiberal state" by virtue of his consciousness. "As long as the artist invents and is enthusiastic", he is in danger of blindly falling prey to his interest in the object and his own will to express it. Only when he is "no longer interested" in his object, only when he no longer wants to "say everything", no longer wants to "talk himself out" fully, does he gain the prudence of the artist (Strohschneider-Kohrs, 1978, pp. 5051). Friedrich Schlegel describes this act of elevation above oneself with terms that again recall Fichte's thinking on "self-creation" and "selfrestraint". This is what he means by the process of artistic creation. A conscious, deliberate restriction must follow the stage of initial enthusiasm and invention so that "obstinacy", unbridled whim or "instinctive drive" do not sweep the artist away and make him a "servant" (Strohschneider-Kohrs, 1978, pp. 50-51).

Auffenberg (1993) sees this Romantic attitude towards an "equally enthusiastic and distanced-critical act of poetic creation" (p. 179) as the literary-historical background to the dialectical relationship between fantasy and reflection set by Grass. Furthermore, Auffenberg (1993) notes a connection between the background of Grass's narrative relativism and the Romantic understanding of the world, especially with Friedrich Schlegel's concept of irony. ${ }^{7}$

Dualism, mirrored through the interaction of imagination and reflection, is again represented in the novel "The Tin Drum" in the form of Oskar's 'favourite gods' Apollo and Dionysus.

I follow this provision in the novel "A Wide Field". See in Yelena Etaryan (2020): Formen literarischer Selbstreflexion bei Thomas Mann und Günter Grass. Königshausen \& Neumann.
When the novel bases Oskar's ego disposition on the duality of Apollo and Dionysus, it problematises his understanding of art, which is borne by measure and intoxication. Dualism consists in the juxtaposition of form, order, mastery and chaos, ecstasy, disharmony.

The two spheres would then be parallelised with the sphere of reflection and imagination in the individual and abbreviated following Nietzsche's dialectic. Returning to Grass's definition of "shades of grey", here is Auffenberg's (1993) definition of Grass's problem of dualism: "The 'shades of grey' and the dominant antithetical structure of his narrative suggest that he balances dualisms and thereby illuminates the third possibility, the realisation of ambivalence" (p. 184).

In the following quotation, Brigitte ZisselMay (1974), who addresses the relationship between language and reflection by Grass, contrasts ratio and the linguistic shaping of fantasy: "Grass then subjects the initially irrational, fantastic idea to a strict linguistic shaping, which is under the sign of ratio and cancels out the autonomy of fantasy. ...Language functions as a kind of control. In it, the two poles of fantasy and reality meet and are fused into a unity in which the fantastic takes on realistic features and the real a fantastic touch, but reality always forms the supporting background" (p. 33).

In summary, it can be said that ambivalence is Grass's world principle and world view and that art has the task of transporting the world and reality in their dialectical structure and thereby initiating processes of cognition.

In the speech "The Artist's Freedom of Expression in Our Society" (Grass, 1987b, pp. 614-623), the artist emerges as a partisan and enlightener. His understanding of the artist results from his political self-image and his confession to be distanced from any ideology. In another speech, he notes the following: "All ideologies that inevitably lead to systems must be considered dangerous... Our freedom has its 
great chance in not being dogmatically fixed (Grass, 1987a, p. 59)".

In "The Tin Drum", Grass postulates the role of the artist as a self-legitimised resistance fighter whose resistance is free of systemic constraints and of his own accord. His goal is the refusal of totality and opposition to the establishment of power.

The role of the artist, postulated in "The Tin Drum", in turn becomes a constant in the work of Günter Grass: art becomes a medium of rebellion against a politically, socially and historically one-dimensional and thus reduced reality. It is revealing how Bruno Münsterberg renders Oskar's "partisan thesis": "Incorrigible, self-subverting partisans are ... of all people devoted to politics the most artistically gifted, because they immediately discard what they have just created" ("Unverbesserliche, sich selbst unterwandernde Partisanen sind ... unter allen der Politik verschriebenen Menschen die künstlerisch begabtesten, weil sie sofort verwerfen, was sie gerade geschaffen haben.") (Grass, 1987e, p. 522). (Emphasis: Y.E.)

Knowing that "intolerance is also practised by artists and in the interest of exclusive art ideology", that "entire art movements ... have not only been fellow followers but also pioneers of totalitarian ideas", Grass (1987b, pp. 617-618) establishes a type of artist who always remains dissatisfied in the face of what has been created.

This ultimately leads to the constant stocktaking or negation of what has been achieved in each case, in other words - to the process of polarisation of "creating" and "discarding". For this reason, a work of art must never be seen as a finished product; it must constantly be in the process of becoming and always in the process of distancing and questioning itself. Elevating the artwork to a means of critique offers parallels to the aesthetic-philosophical concepts of the Romantics, as already mentioned, in terms of the circular process of self-creation and self-destruction and the role of the artist to be a critic of himself. This point of view results in the artist's re- sponsibility and obligation towards society, which in turn brings us close to the Romantics.

The principle of "creating" and "discarding" is once again present in Bruno's working style, as he himself notes: "But like that partisan whom Herr Matzerath praises to me as a model, I remain restless and dissatisfied; what I knot on the right I dissolve on the left, what my left forms, my clenched right smashes”. („Doch ähnlich jenem Partisanen, den mir Herr Matzerath als Muster preist, bleibe ich rastlos und unzufrieden; was ich rechts knüpfe, löse ich links auf, was meine Linke bildet, zertrümmert meine geballte Rechte“.) (Grass, 1987e, p. 522).

This, in turn, reminds us of the narration of Oskar. Christian Auffenberg (1993) concludes it in terms of aesthetic reception that Grass, through Oskar's contradictory narration, equally incites the reader to partisanship by depriving him of the basis for an evaluation, constantly compelling him to revise his own judgement, causing him to remain open in his opinion, to create and reject the opinion for his part. The Grassian artistic understanding that can be derived from this in the sense of postmodernism would mean that everything is possible simultaneously and contradictorily, that truth and reality are fundamentally indeterminable because they are ambiguous.

For Grass (1987), Camus Sisyphus's figure provides an example of the incompleteness of the process of "creating" and "discarding". He writes: "This Camus's position has become topical to me again. Sisyphus is topical again. I recognise myself at the foot of the mountain, and the stone is there, I roll it.... It was written, thought out of the realisation that we have to move the stone, although we know that it won't stay at the top. This is the denial of an ultimate goal. It is the rejection of any closed ideological system that extols a state to us and wants to move people in one direction. It wants to make them believe that we will achieve something, a state where the stone remains, where this longed-for position is finally reached. I have already denied this in the snail diary with other arguments: Snails never 
arrive" (Grass, 1987a, pp. 279-280). ${ }^{8}$

The knotwork of infirmary's nurse Bruno Münsterberg can be interpreted as a metaphor, as well as Grass's aesthetic position. Oskar comments on Bruno's occupation as follows: "He knots ordinary twine, which he collects and untangles in his patients' rooms after visiting hours, into multi-layered knotted ghosts, then dips them in plaster, lets them solidify and impales them with knitting needles attached to wooden skirting." ("Er knotet ordinäre Bindfäden, die er nach den Besuchsstunden in den Zimmern seiner Patienten sammelt und entwirrt, zu vielschichtig verknorpelten Gespenstern, taucht diese dann in Gips, läßt sie erstarren und spießt sie mit Stricknadeln, die auf Holzsöckelchen befestigt sind.) (Grass, 1987e, p. 6)

Christian Auffenberg (1993) emphasises that this 'artistic process' refers to a reflection of aesthetic productivity: "In the process of knotting, the novel allegorises the (content-related and formal) principle of the production of its narrative" (p. 43). Moreover, threads and knots are a metaphor of narrative used several times by Grass. The novel "A Wide Field", too, refers to the modality of narration and the receptive task of the reader: "Unravelling their voices, patiently unravelling the overlapping talk - we often heard mother and daughter at the same time" (,Ihre Stimmen entflechten, geduldig das überlappte Gerede aufdröseln - oft hörten wir Mutter und Tochter zugleich“) (Grass, 1998, p. 216) - it is reported at the beginning of chapter XI by the Archive on Fonty's wife and daughter. For the reader, the task is to "disentangle" and "unravel" the narrative levels as well as the aforementioned "talk". In both works, the knot consists of a network of slices of reality and associations.

The literary metaphor of the knot in the novel is also linked to that of unravelling: While Bruno unravels the strings of gift wrapping and weaves them into new figures, Oskar unravels memories on his drum and tries to "eloquently unravel his

8 According to my position, the "denial of an ultimate goal" underlies the title of "A Wide Field" itself. tangled history.” („Verworrene Geschichte wortreich zu entwirren“) (Grass, 1987e, p. 7). ${ }^{9}$ Auffenberg (1993) understands the process of unravelling as "not a hasty, not rash or superficial, but patient, thoughtful and critical engagement with reality" (p. 216). ${ }^{10}$

Another characteristic of partisanship is that one acts from the background, as the text itself testifies: "According to my nature, Oskar kept in the background during the actions" (,Meiner Natur entsprechend hielt Oskar sich während der Aktionen im Hintergrund.") (Grass, 1987e, p. 457). Oskar explains to Mr Bebra: "You know, Mr Bebra, I prefer to count myself among the spectators, let my little art blossom in secret, away from all the applause.” (,Wissen Sie, Herr Bebra, ich rechne mich lieber zu den Zuschauern, laß meine kleine Kunst im Verborgenen, abseits von allem Beifall blühen.") (Grass, 1987e, p. 132).

A parallel passage from "A Wide Field" for us is the letter that Fonty, the main character of the novel, writes to his daughter Martha Wuttke on the occasion of the opening of the Berlin Wall. ${ }^{11}$ The following quote describes the events mentioned and the main characters' reaction to them: "...Mama, of course, stooped to tears, while to me such events, which partout want to be big, mean very little. I'd rather concentrate on the details, for example on those young boys, among them exotic foreigners, who, as so-called wall-pickers or wall-peckers, carry out the undoubtedly welcome demolition of this kilometrelong achievement partly as iconoclasm, partly as petty trade; they get to grips with the all-German work of art with hammer and chisel ... so that everyone - and there is no lack of customers gets their souvenir. (,....Mama hat sich natürlich zu Tränen verstiegen, während mir solche

\footnotetext{
9 Cf. pp. 66, 516.

10 The thematic focus of this metaphor (the process of haste, the superficial) forms one of Günter Grass's criticisms of the process of German reunification, which found its way into the novel "A Wide Field".

11 In the novel, the fall of the Berlin Wall and the reunification of Germany are at the centre of the plot.
} 
Ereignisse, die partout groß sein wollen, herzlich wenig bedeuten. Eher setze ich aufs aparte Detail, zum Beispiel auf jene jungen Burschen, unter ihnen exotisch fremdländische, die als sogenannte Mauerpicker oder Mauerspechte den zweifelsohne begrüßenswerten Abbruch dieser kilometerlangen Errungenschaft teils als Bildersturm, teils als Kleinhandel betreiben; sie rücken dem gesamtdeutschen Kunstwerk mit Hammer und Meißel zu Leibe ... auf daß jedermann und es fehlt nicht an Kundschaft - zu seinem Souvenir kommt.“) (Grass, 1998, pp. 10-11).

As far as the role of the artist as enlightener is concerned, Grass (1987a) formulates the enlightenment intentions underlying arts as follows: "Man must be unmasked, the clichés must be shattered, the outer facades torn down so that the actual existence can become visible" (p. 6).

This conception of art is epitomised in the Tribunes chapter of "The Tin Drum", specifically in the description of its rear view. First and foremost, Oskar shows the misuse of a tribune by presenting himself as an analysing and critical aesthete who wants to bring to light a critical consciousness in the face of pomposity. Thus, he poses the following question to the readers: "Have you ever seen a tribune from behind? All people should be familiarised ... with the rear view of a tribune before they are gathered in front of tribunes. Anyone who has ever looked at a tribune from behind looked at it properly, will be marked from the hour and thus be immune to any sorcery that is celebrated in this or that form in tribunes”. („Haben Sie schon einmal eine Tribüne von hinten gesehen? Alle Menschen sollte man ... mit der Hinteransicht einer Tribüne vertraut machen, bevor man sie vor Tribünen versammelt. Wer jemals eine Tribüne von hinten anschaute, recht anschaute, wird von Stund angezeichnet und somit gegen jegliche Zauberei, die in dieser oder jener Form auf Tribünen zelebriert wird, gefeit sein.") (Grass, 1987e, pp. 138-139).

In this way, Oskar clarifies the deceptive and lying façades, which we will follow later in the novel "A Wide Field" in view of, as it has been mentioned, a different historical period. In "The Tin Drum", the narration is equated with the uncovering of a façade-like quality; its critique is accepting the external form, which excludes any questioning of more profound content. However, the novel "The Tin Drum" makes up for this.

\section{Conclusion}

From the above, the following can be concluded:

The historical and cultural reality in the two novels is presented in multiple perspectives: in "A Wide Field", the reality of reunified Germany is meant, and in "The Tin Drum" - the understanding of art which is thematised by different types of artists. The "narrated" reality is commented on by different "voices", i.e. by the narrative collective ("A Wide Field") and novel characters ("A Wide Field", "The Tin Drum"). In this way, Grass realises his philosophicalaesthetic principle of "extended reality". The former is reflected, among other things, in the "we" form of the narrator ("A Wide Field").

In addition, the background perspective derived from "The Tin Drum", which is reflected in the narrative perspective from the point of view of those affected in the novel "A Wide Field", makes it possible in the case of the first novel to portray the guilt of each individual German during the Nazi era and, in the second case, the dark sides of the reunified Germany. In this way, a kind of oral history is created in both cases, which is reflected in the narrative principle. We are talking about the depiction of the small, the inconspicuous, the insidious, the invisible on the surface, in contrast to the large and pompous events of the present. In this way, the author Grass deconstructs the expectations of the reader and plays the game of self-thematization and self-abrogation of literature that he has known since "The Tin Drum". This brings him close to the Romantics and specifically to the Romantic principle of literary self-reflection. 
For this reason, a work of art must never be seen as a finished product: it must constantly be in the process of only becoming and always in the process of distancing and questioning itself.

\section{References}

Auffenberg, Ch. (1993). Vom Erzählen des Erzählens bei Günter Grass. Studien zur immanenten Poetik der Romane „Die Blechtrommel“ und „Die Rättin“ (On the narration of narration in Günter Grass. Studies on the immanent poetics of the novels "The Tin Drum" and "The Rat", in German). Münster u.a.: Lit.

Etaryan, Y. (2020). Formen literarischer Selbstreflexion bei Thomas Mann und Günter Grass (Forms of literary selfreflection by Thomas Mann and Günter Grass, in German). Würzburg: Königshausen \& Neumann.

Grass, G. (1987a). Werkausgabe in zehn Bänden. Bd. X. Gespräche mit Günter Grass (Works in ten volumes. Vol. X. Conversations with Günter Grass, in German). (V. Neuhaus, Hg.). Darmstadt u. a: Luchterhand.

Grass, G. (1987b). Werkausgabe in zehn Bänden. Bd. IX. Essays/Reden/Briefe/ Kommentare (Works in ten volumes, Vol. IX. Essays/Speeches/Letters/Commentaries, in German). (V. Neuhaus, Hg.). Darmstadt u. a: Luchterhand.

Grass, G. (1987c). Werkausgabe in zehn Bänden. Bd. V. Der Butt (Works in ten volumes,
Vol. V. The Flounder, in German). (V. Neuhaus, Hg.). Darmstadt u. a: Luchterhand.

Grass, G. (1987d). Werkausgabe in zehn Bänden. Bd. IV. Örtlich betäubt. Aus dem Tagebuch einer Schnecke (Works in ten volumes, Vol. IV. Locally stunned. From the Diary of a Snail, in German). (V. Neuhaus, Hg.). Darmstadt u. a: Luchterhand.

Grass, G. (1987e). Werkausgabe in zehn Bänden. Bd. II. Die Blechtrommel (Works in ten volumes, Vol. II. The Tin Drum, in German). (V. Neuhaus, Hg.). Darmstadt u. a: Luchterhand.

Grass, G. (1998). Ein weites Feld (A wide field, in German). München: dtv.

Schlegel, F. (1882). 1794-1802: Seine prosaischen Jugendschriften (His prosaic juvenile writings, in German). (J. Minor, Hg.). (Bd. II). Wien: Konegen.

Strohschneider-Kohrs, I. (1978). Zur Poetik der deutschen Romantik II: Die romantische Ironie (On the Poetics of German Romanticism II: Romantic Irony, in German). In H. Steffen (Hg.), Die deutsche Romantik (German Romanticism, in German) (pp. 11-58). Göttingen: Vandenhoeck \& Ruprecht.

Zissel-May, B. (1974). Gegenständlichkeit und Weltbild. Eine Untersuchung zur Lyrik von Günter Grass (Representationalism and world view. An investigation into the poetry of Günter Grass, in German). Bern, Frankfurt a.M.: Verlag Universität. 